\title{
УСОВЕРШЕНСТВОВАНИЕ ТЕХНОЛОГИИ ГИДРОЛИЗА СЫРЬЯ МАРАЛОВ
}

\section{G. Krotova}

\section{IMPROVING THE TECHNOLOGY OF HYDROLYSIS OF MARALS' RAW MATERIALS}

Кротова Мария Георгиевна - канд. с.-х. наук, ст. науч. сотр. лаб. переработки и сертификации пантовой продукции Всероссийского НИИ пантового оленеводства - отдела Федерального Алтайского научного центра агробиотехнологий, г. Барнаул. E-mail: wniipo@rambler.ru

Изучено влияние различных концентраций этилового спирта, глицерина и гиппохлорита на процесс ферментативного гидролиза сырья маралов. В качестве материала использовали побочную продукцию пантового оленеводства (сухожилия, репродуктивные органы самиов, матки с эмбрионами и околоплодной жидкостью). Гидролиз осуществляли в ультразуковой установке при гидромодуле $1: 5,1: 10$ при температуре $50{ }^{\circ} \mathrm{C}$ в течение 4, 6, 10 ч. Ферментацию проводили с применением ферментов микробного происхождения Протозим $B$, Протозим С и Протозим ЛП, вносимых в раствор в количестве 0,5 \% от объема сырья. Установлено, что добавление этанола при гидролизе сырья маралов в количестве $1 \%$ оm объема воды способствует увеличению выхода сухих веществ по сравнению с контрольными образцами в 2,1 раза при переработке сухожилий, на 23,8 \% - при гидролизе маток, на 12,9 \% - при форментации репродуктивных органов самцов. Применение глицерина в процессе гидролиза сухожилий позволило увеличить выход сухого вещества в 2,0 раза по сравнению $c$ контролем при количестве глицерина $3 \%$. Оценка органолептических свойств концентратов показала, что оптимальным является применение этанола в концентрации 1 \%. Показано, что применение низких концентраций органических растворителей при протеолизе сырья маралов позволило сократить время экстракции в 1,3-1,6 раза по сравнению с технологией ферментации без добавления этилового спирта. Установлено, что при фрерментации сырья в присутствии органических рас-
Krotova Maria Georgievna - Cand. Techn. Sci., Senior Staff Scientist, Lab. of Processing and Certification of Antler Production, All-Russia Research Institute of Antler Reindeer Breeding - Branch of Alta Federal Scientific Center of Agrobiotechnologies, Barnaul. E-mail: wniipo@rambler.ru

творителей увеличение гидромодуля приводит к снижению выхода концентрата, показано, что оптимальным является гидромодуль $1: 5$.

Ключевые слова: сырье, марал, гидролиз, ферментация, концентрат, органический растворитель.

The effect of various concentrations of ethyl alcohol, glycerol and hypochlorite on the process of enzymatic hydrolysis of maral raw materials was studied. By-products of velvet antler deer farming (tendons, reproductive organs of stags, uteri with embryos and amniotic fluid) were used as the material. Hydrolysis was carried out in ultrasound installation at hydromodule 1: 5, 1:10 at the temperature of $50{ }^{\circ} \mathrm{C}$ during 4, 6, 10 hours. The fermentation was carried out with using enzymes of microbic origin Protozyme $B$, Protozyme $C$ and Protozyme $L P$, brought in solution in the number of $0.5 \%$ of raw materials volume. It was found that the addition of ethanol in the amount of $1 \%$ of water volume during the hydrolysis of maral raw materials led to the increase in the yield of dry substances compared to the control samples; specifically, the yield of dry substances increased by 2.1 times for the processing of tendons, by $23.8 \%$ for the hydrolysis of uteri, and by $12.9 \%$ for the fermentation of reproductive organs of stags. Using glycerin for the hydrolysis of tendons allowed obtaining the increase in the yield of dry substances by 2.0 times compared to the control samples, when the amount of glycerol was $3 \%$. According to the assessment of organoleptic properties of the concentrates, using ethanol at the concentration of $1 \%$ was found to be optimal. It was shown that using low concentration of organic 
solvents at proteolysis of raw materials of marals allowed reducing extraction time by 1.3-1.6 times compared to the fermentation technology without ethyl alcohol. It was established that at raw materials fermentation in the presence of organic solvents the increase in the hydromodule led to the decrease in the exit of the concentrate, it was shown that hydromodule 1 had been optimum: 5 .

Keywords: raw materials, maral, hydrolysis, fermentation, concentrate, organic solvent.

Введение. Известно, что Алтай является традиционной зоной обитания маралов, эндемичным видом данной территории. В Алтайском крае и Республике Алтай сконцентрировано порядка $90 \%$ пантовых оленей Российской Федерации [1]. Одним из интенсивно развивающихся и перспективных направлений пантового оленеводства является усовершенствование технологий глубокой переработки сырья, которые должны способствовать повышению эффрективности использования пантовой продукции и созданию безотходного производства на марало- и оленесрермах. Расширение спектра технологий переработки, а также создание возможности использования нового сырья в различных продуктах позволят повысить рентабельность мараловодческих предприятий Алтайского края.

На сегодняшний день наиболее перспективным способом переработки сельскохозяйственного сырья, в особенности вторичного, является гидролитическое расщепление с применением ферментных препаратов [2, 3].

Сотрудниками ФГБНУ ФАНЦА проведены научные исследования по переработке основной и побочной продукции пантового оленеводства с применением ферментов растительного, животного и микробного происхождения [4-6]. Согласно полученным данным, применение технологии ферментации позволило значительно увеличить процент перехода сухого вещества сырья в гидролизат (до 98 \%) при переработке хвостов марала. Однако при ферментации репродуктивных органов самцов, сухожилий и маток с эмбрионами в растворимую форму концентрата переходило 65-71 \% от массы сырья [7], при этом от 30 до $40 \%$ компонентов сырья оставалось в виде жмыха. Известно, что средняя проба оставшегося жмыха из побочного сырья по содержанию белка превосходит: панты в 1,3 раза, жир - в 4,3 раза, аминокислоты - на 16,9 \% [8]. Следовательно, существует необхо- димость дальнейшего совершенствования технологии переработки для максимально полного извлечения биологически активных компонентов продукции оленеводства.

Согласно литературным данным, некоторые органические растворители обладают активационным влиянием на фрерментные препараты [9], что обусловлено изменением связывания субстрата с фрерментами за счет увеличения липофильности реакционной среды [10]. Данное действие обусловлено замещением воды в гидратной оболочке белковой глобулы на молекулы органического растворителя, что приводит к увеличению растворимости субстратов. Исходя из имеющихся литературных данных, было выдвинуто предположение, что проведение ферментации сырья маралов в присутствии органических растворителей позволит повысить глубину гидролиза и повысить выход сухих веществ в гидролизат.

Важным является выбор растворителя, а также определение его оптимальной концентрации для установления максимальной каталитической активности ферментных систем.

Цель исследования: усовершенствование способа ферментативного гидролиза сырья маралов путем добавления в раствор органических растворителей.

Материалы и методы исследования. Исследование проведено на базе ФГБНУ ФАНЦА отдела «ВНИИПО» в 2019 г.

Материалом исследования служило побочное сырье маралов, в частности сухожилия, репродуктивные органы самцов, матки с эмбрионами и околоплодной жидкостью, предварительно измельченные до состояния фарша на промышленном измельчителе МИМ-300.

Проведена серия опытов по интенсификации ферментативного гидролиза сырья путем добавления низких концентраций органических растворителей. В качестве органических растворителей апробировали этиловый спирт $\left(98^{\circ} \mathrm{C}\right)$, глицерин (ЧДА), гиппохлорит (физиологический раствор). Концентрация этилового спирта в реакционной смеси составляла $1 ; 3 ; 6$ $\%$, концентрация глицерина - 0,5; 1 ; $3 \%$, концентрация гиппохлорита составляла 39 и 180 мг/л. Первоначально исследовано влияние различных концентраций этанола, глицерина и гиппохлорита на активность фрерментов при расщеплении сырья маралов. 
Гидролиз осуществляли при температуре $50^{\circ} \mathrm{C}$ на ультразвуковой установке Elmasonik. Протеолиз проводили при гидромодуле 1:5 и 1:10 в течение 4, 6 и 8 ч. В ранее проведенных исследованиях по гидролизу сырья пантовых оленей установлено, что наилучшие результаты получены при использовании комплекса фрерментов Протозим В, Протозим С и Протозим ЛП, поэтому в дальнейших исследованиях применялись данные ферментные препараты. Концентрация фрерментного комплекса составляла 0,5\% от объема субстрата. Проведено сравнение выхода сухих веществ после гидролиза в присутствии органических растворителей путем высушивания полученных образцов гидролизатов в инсракрасной сушке при температуре $50^{\circ} \mathrm{C}$ и взвешивания полученных биосубстанций. В качестве контроля использовали образцы гидролизатов, полученные путем фрерментации сырья без применения органических растворителей.

Результаты исследования. На первом этапе исследования нами было изучено влияние различных концентраций органических растворителей на выход сухих веществ (концентрата) сырья маралов (табл.).

\section{Выход концентрата при ферментации сухожилий марала в присутствии органических растворителей}

\begin{tabular}{|l|c|c|}
\hline \multicolumn{1}{|c|}{ Экстрагент } & Концентрация экстрагента & Выход концентрата, \% \\
\hline \multirow{3}{*}{ Этиловый спирт, \% } & 1 & $97,5 \pm 1,25$ \\
\cline { 2 - 3 } & 3 & $86,9 \pm 1,15$ \\
\cline { 2 - 3 } & 6 & $80,0 \pm 0,93$ \\
\hline \multirow{3}{*}{ Глицерин, \% } & 0,5 & $80.0 \pm 0,56$ \\
\cline { 2 - 3 } & 1 & $91,6 \pm 0,71$ \\
\hline \multirow{2}{*}{ Гиппохлорит, мг/л } & 3 & $95,8 \pm 1,34$ \\
\hline Контроль & 39 & $62,5 \pm 0,97$ \\
\cline { 2 - 3 } & 180 & $66,7 \pm 0,84$ \\
\hline
\end{tabular}

Как видно из таблицы 1, применение этилового спирта в процессе ферментативного гидролиза сухожилий позволило увеличить выход концентрата в 2,1 раза по сравнению с контролем при концентрации этанола в растворе $1 \%$, разница достоверна с вероятностью $p \leq 0,001$. Увеличение концентрации этанола в водноспиртовой смеси до 3-6 \% являлось нецелесообразным ввиду менее эфффективного воздействия на активность ферментов по сравнению с $1 \%$ раствором.

При использовании в качестве органического растворителя глицерина, напротив, наблюдалась прямая зависимость, при увеличении его концентрации в растворе увеличивался выход концентрата. Применение глицерина в процессе гидролиза позволило увеличить выход сухого вещества в 2,0 раза по сравнению с контролем при количестве глицерина $3 \%$. Оценка органолептических свойств концентрата, полученного при использовании глицерина, показала, что полученный гидролизат при высушивании в течение 24 ч сохраняет высокие адгезивные свойства и высокую вязкость, не поддается измельчению, на основании чего считаем нецелесообразным применение глицерина для увеличения липофильности реакционной среды при проведении протеолиза.

Применение в качестве экстрагента активного раствора гипохлорита натрия в сочетании с ферментными препаратами оказало минимальное влияние на процесс гидролиза. Выход концентрата увеличился на 36,7-45,9 \% по сравнению с контролем.

Для подтверждения эффрективности применения этилового спирта при ферментации сырья маралов данные технологические параметры были применены при гидролизе репродуктивных органов самцов марала, маток с эмбрионами и околоплодной жидкостью. Полученные данные представлены на рисунке 1. 


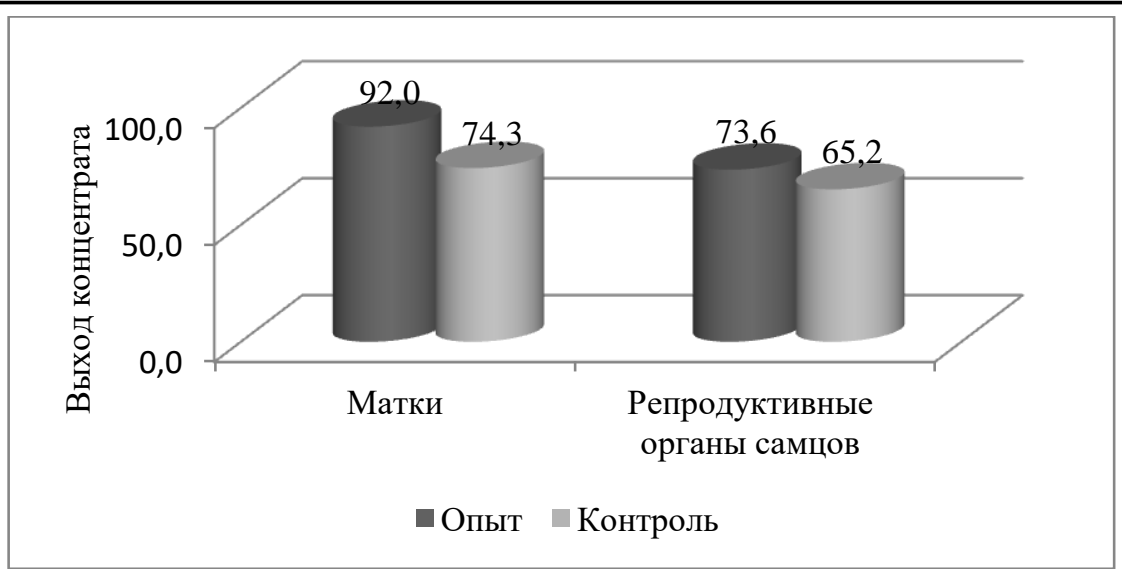

Puс. 1. Выход концентрата при гидролизе сырья маралов, \%

Технология фрерментативного гидролиза сырья маралов с добавлением этилового спирта в количестве 1 \% позволила увеличить выход сухих веществ (концентратов) по сравнению с контрольными образцами на 23,8 \% при переработке маток с эмбрионами и околоплодной жидкостью, на 12,9 \% - при гидролизе репродуктивных органов самцов. Полученные данные согласуются с существующими исследованиями, согласно которым низкие концентрации этилового спирта способствуют повышению активности ферментов на казеиновом субстрате. Согласно литератур- ным данным, для фрермента химотрипсин необходимо наличие определенной протяженности гидрофобных участков в субстрате, но в присутствии органических растворителей химотрипсин теряет выраженную специфичность к гидрофобности субстратов [11].

Во второй серии опытов было исследовано влияние этанола на скорость протеолиза. Продолжительность гидролиза образцов составляла от 4 до 8 ч. Полученные данные представлены на рисунке 2.

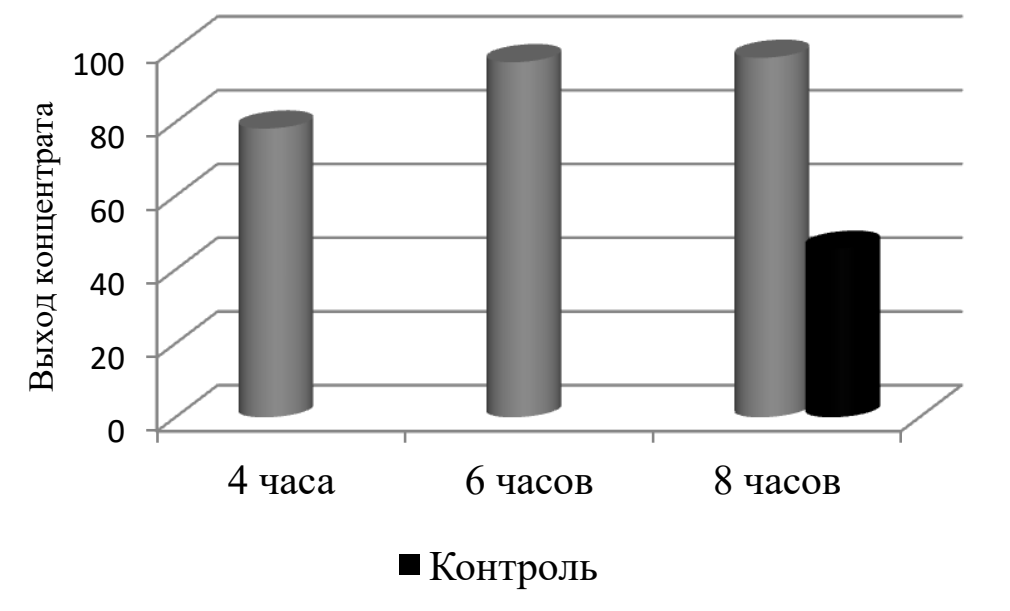

Pис. 2. Динамика выхода концентрата в зависимости от продолжительности протеолиза, \%

Исходя из полученных данных, использование этилового спирта при ферментации сухожилий марала позволило сократить время ферментации. Выход концентрата в контрольном образце, полученном при ферментативном гидролизе в отсутствии этанола в течение 10 ч, составил 45,7 \%. При добавлении этилового спирта уже через 4 ч экстракции выход концентрата увеличился на 71,3\%, через 6, 8 ч - в 2,1 раза $(p \leq 0,001)$. В соответствии с выходом концентрата и затратами энергии и труда на производство гидролизата оптимальным является гидролиз в течение 6 ч.

Проведено влияние гидромодуля на выход концентрата при фрерментативном гидролизе. Полученные данные представлены на рисунке 3. 


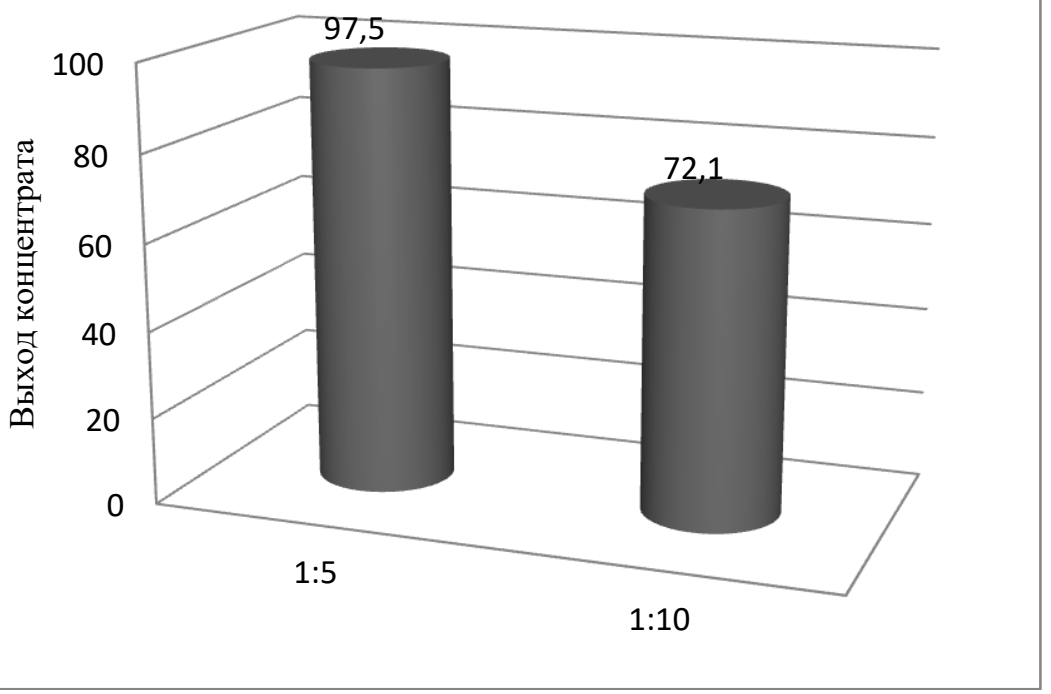

Puc. 3. Выход концентрата в зависимости от гидромодуля, \%

Показано, что при увеличении гидромодуля в 2 раза выход концентрата снижается на $35,2 \%$, что обусловлено снижением насыщенности раствора ферментами.

Таким образом, процесс ферментативного гидролиза в процессе переработки сырья маралов можно усовершенствовать увеличением липофильности реакционной среды путем замены водного раствора реакционной смеси на водноспиртовой.

\section{Выводы}

1. Добавление этанола в количестве $1 \%$ от объема водной фазы в процессе ферментативного гидролиза сырья маралов приводит к увеличению выхода сухих веществ в 2,1 раза при переработке сухожилий, на 23,8 \% - при гидролизе маток, на 12,9 \% - при фрерментации репродуктивных органов самцов по сравнению с контрольными образцами.

2. Применение низких концентраций органических растворителей при протеолизе сырья маралов позволило сократить время экстракции в 1,3 раза по сравнению с технологией ферментации без добавления этилового спирта.

3. Применение глицерина в процессе гидролиза позволило увеличить выход сухого вещества в 2,0 раза по сравнению с контролем при количестве глицерина $3 \%$.

4. Оценка органолептических и количественных характеристик полученных концентратов показала, что оптимальным является проведение ферментативного гидролиза в присутствии этилового спирта в концентрации 1 \% при гидромодуле $1: 5$ и времени экстракции 6 ч.

\section{Литература}

1. Неприятель А.А. Результаты изучения способов консервирования пантов маралов, обитающих в различных регионах РФ // 30отехния. 2019. № 11. С. 28-30.

2. Белоусова С.В., Косенко О.В. Влияние фрерментативных препаратов на глубину гидролиза коллагенсодержащего сырья // Изв. ву3ов. Пищевая технология. 2012. № 4. С. 8486.

3. Зинина О.В., Соловьева А.А., Резебов Я.М. и др. Ферменты в мясной отрасли пищевой промышленности // Международный студенческий научный вестник. 2015. № 6.49 с.

4. Луницын В.Г., Гришаева И.Н. Способ получения биологически активного концентрата из консервированных пантов // Патент на изобретение RU 2461384 C1, 20.09.2012. Заявка № 2011107523/15 от 25.02.2011. URL: https://yandex.ru/patents/doc/RU2461384 C1 20120920.

5. Луницын В.Г., Абашева О.В., Белозерских И.С., и др. Усовершенствование способа переработки побочной продукции пантового оленеводства // Проблемы пантового оленеводства и пути их решения: сб. науч. тр. Барнаул: Азбука, 2014. Т. 8. С. 81-84.

6. Белозерских И.С. Совершенствование метода производства биосубстанций из субпродуктов марала // Актуальные проблемы сель- 
ского хозяйства горных территорий: мат-лы VII науч.-практ. конф., посвящ. 70-летию Горно-Алтайского государственного университета. Горно-Алтайск, 2019. С. 425-428.

7. Кротова М.Г., Гришаева И.Н., Пшеничникова E.H.u др. Переработка жмыха из побочной продукции мараловодства // Научные исследования для АПК в Сибири и Казахстане / Федер. Алтайский науч. центр агробиотехнологий. Барнаул, 2018. С. 65-69.

8. Луницын В.Г., Неприятель А.А. Современные способы переработки продукции мараловодства. Барнаул, 2015. 25 с.

9. Беляева Е.А., Еремеев Н.Л. Кинетическая демонстрация локальных конформационных изменений вблизи активного центра а-химотрипсина в смесях вода-диметисульфроксид // Вестник МГУ. Сер. 2. Химия. 2000. T. 41, № 6. C. 392-394.

10. Белова А.Б., Можаев В.В., Левашов А.В. Взаимосвязь ффизико-химических характеристик органических растворителей с их денатурирующей способностью по отношению к белкам // Биохимия. 1991. Т. 56, вып. 11. C. 1923-1945.

11. Давидович В.В., Пивненко Т.Н. Влияние липосиильности реакционной среды на процесс ферментативного гидролиза в технологии БАД «Маллюскам» // Известия ТИНРО. 2006. Т. 146. С. 300-305.

\section{Literatura}

1. Neprijatel' A.A. Rezul'taty izuchenija sposobov konservirovanija pantov maralov, obitajushhih v razlichnyh regionah RF // Zootehnija. 2019. № 11. S. 28-30.

2. Belousova S.V., Kosenko O.V. Vlijanie fermentativnyh preparatov na glubinu gidroliza kollagensoderzhashhego syr'ja // Izv. vuzov. Pishhevaja tehnologija. 2012. № 4. S. 84-86.

3. Zinina O.V., Solov'eva A.A., Rezebov Ja.M., Fermenty v mjasnoj otrasli pishhevoj promyshlennosti // Mezhdunarodnyj studencheskij nauchnyj vestnik. 2015. № 6.49 c.
4. Lunicyn V.G., Grishaeva I.N. Sposob poluchenija biologicheski aktivnogo koncentrata iz konservirovannyh pantov // Patent na izobretenie RU 2461384 S1, 20.09.2012. Zajavka № 2011107523/15 ot 25.02.2011. URL: https://yandex.ru/patents/doc/RU2461384 C1_20120920.

5. Lunicyn V.G., Abasheva O.V., Belozerskih I.S. $i d r$. Usovershenstvovanie sposoba pererabotki pobochnoj produkcii pantovogo olenevodstva // Problemy pantovogo olenevodstva i puti in reshenija: sb. nauch. tr. Barnaul: Azbuka, 2014. T. 8. S. 81-84.

6. Belozerskih I.S. Sovershenstvovanie metoda proizvodstva biosubstancij iz subproduktov marala // Aktual'nye problemy sel'skogo hozjajstva gornyh territorij: mat-ly VII nauch.prakt. konf., posvjashh. 70-letiju GornoAltajskogo gosudarstvennogo universiteta. Gorno-Altajsk, 2019. S. 425-428.

7. Krotova M.G., Grishaeva I.N., Pshenichnikova E.N. I dr. Pererabotka zhmyha iz pobochnoj produkcii maralovodstva // Nauchnye issledovanija dlja APK v Sibiri i Kazahstane / Feder. Altajskij nauch. centr agrobiotehnologij. Barnaul, 2018. S. 65-69.

8. Lunicyn V.G., Neprijatel' A.A. Sovremennye sposoby pererabotki produkcii maralovodstva. Barnaul, 2015. $25 \mathrm{~s}$.

9. Beljaeva E.A., Eremeev N.L. Kineticheskaja demonstracija lokal'nyh konformacionnyh izmenenij vblizi aktivnogo centra a-himotripsina $v$ smesjah voda-dimetisul'foksid // Vestnik MGU. Ser. 2. Himija. 2000. T. 41, № 6. S. 392-394.

10. Belova A.B., Mozhaev V.V., Levashov A.V. Vzaimosvjaz' fiziko-himicheskih harakteristik organicheskih rastvoritelej $\mathrm{s}$ in denaturirujushhej sposobnost'ju po otnosheniju k belkam // Biohimija. 1991. T. 56, vyp. 11. S. 1923-1945.

11. Davidovich V.V., Pivnenko T.N. Vlijanie lipofil'nosti reakcionnoj sredy na process fermentativnogo gidroliza v tehnologii BAD «Malljuskam» // Izvestija TINRO. 2006. T. 146. S. $300-305$. 